\title{
Effect of Orally Administered Glutathione Peroxidase Mimetic towards Glutathione and Malondialdehyde Blood Level and Otoacoustic Emissions Result in Soldiers with Acoustic Trauma Risk Caused by Howitzer 105 Artillery Weapon BLAST
}

\author{
S. Sasongko ${ }^{*}$, T. Boesoirie ${ }^{2}$, I. Parwati ${ }^{3}$, H. Sastramihardja ${ }^{4}$, J. Bashirudin $^{5}$ \\ ${ }^{1}$ ENT Department of Medical Faculty General Achmad Yani University/Dustira Army Hospital \\ Indonesia \\ ${ }^{2}$ ENT Department of Medical Faculty Padjadjaran University \\ Indonesia \\ ${ }^{3}$ Clinical Pathologic Department of Medical Faculty Padjadjaran University \\ Indonesia \\ ${ }^{4}$ Clinical Pharmacological Department of Medical Faculty Padjadjaran University \\ Indonesia \\ ${ }^{5}$ ENT Department of Medical Faculty Indonesia University \\ Indonesia \\ *Corresponding author;s email: sieragolftht [AT] yahoo.com
}

\begin{abstract}
Excessive noise exposure may cause mechanical and metabolic (oxidative stress) to the inner ear structure (cochlea), resulting in acoustic trauma (TA). Oxidative stress which caused by increasing of free radical ROS/RNS in the organs of Corti, causing apoptosis and necrosis of cochlear hair cell. Oxidative stress was characterized by increasing of malondialdehyde (MDA), decreasing of glutathione peroxidase (GPx) enzyme, and abnormal otoacoustic emission value (refer). Defense mechanism toward oxidative stress was mediated by endogenous antioxidant enyzme (superoxide dismutase/SOD, catalase/CAT, and GPX). Cellular mechanism of glutation peroxidase mimetic was similar as GPx.

Aim of this study was to determine the impact of glutathione peroxidase mimetic to glutathione peroxidase and malondialdehyde level in blood, also otoacoustic emission value on soldiers with risk of TA due to explosion of Howitzer 105 artillery weapon. The design of this study was clinical trial pre and post design, randomized, double blind and placebo controlled, on 34 new recruit soldiers in Artillery Academy of Indonesian Army, during the soldiers were trained to firing Howitzer 105 artillery weapon, from $7^{\text {th }}-10^{\text {th }}$ July 2014 in Cimahi and Batujajar. Subjects were divided into 2 groups, the exposure group (group given treatment) and control group. Exposure group was given glutathione peroxidase mimetic (Ebselen SPI 1005) $200 \mathrm{mg}$, orally once daily during the training, meanwhile control group was given. Malondialdehyde and Glutathione Peroxidase level in blood, pure tone audiometry and otoacoustic emission value (DPOAEs) was measured from those two groups, before and after firing training. The data was analyzed using parametric and non parametric, with Number Needed to Treat (NNT, 95\%CI) and significance value (p<0.05).

The results of this study showed the number of acoustic trauma events in controle group based on pure tone audiometry test was $23.5 \%$, exposure group was $0 \%$, and based on DPOAEs test the controle group showed $47.1 \%$ abnormal/refer, exposure group showed 100\% normally/pass, and this difference stastically significance $(p<0.051)$. The group which was given Ebselen SPI 1005 showed increasing 82.4\% erythrocyte GPx level (NNT, 95\% CI=1.889 [1.1593.016]; $p=0.004)$, showed increasing 88.2\% plasma GPx level (NNT, 95\%CI=1.417 [0.970-1.775]; p<0.001), decreasing $100 \%$ erythrocyte MDA level $(\mathrm{NNT}, 95 \% \mathrm{CI}=2.125$ [1.335-3.987]; $p=0.01)$, showed decreasing 94.1\% plasma MDA level (NNT, 95\%CI=2.125 [1.29-3.904]; $p=0.01)$, and resulting 100\% in normal/pass DPOAEs value (NNT, 95\%CI = 2.125 [1.335-3.987]; $p=0.01$ ). This study concluded that giving Ebselen SPI 1005 to soldiers with risk of acoustic trauma during the firing Howitzer 105 artillery weapon, increasing GPx level in blood, decreasing MDA level in blood, and resulting normally DPOAEs value (pass).
\end{abstract}

Keywords--- Acoustic trauma, Ebselen, GPx, MDA, Otoacoustic emission 


\section{INTRODUCTION}

The Indonesian National Armed Forces (TNI) soldiers are part of the Indonesians, they must be professionally supported by excellent physical abilities, including the optimal ability of the five senses in carrying out their main tasks. After retirement, they should have keep good physical abilities (including the ability of the five senses), so after returning to the community, they still have a good quality of life.

The Field Artillery Training Center (Pusdik Armed) as armed forces institution uses 105 Howitzer as one of the student training tools since 1985 until these days, with 3-4 times training frequencies per year. When firing the gun, the soldiers are approximately +1 meter apart from the gun. The number of fire ranges is around $2-10$ shots per gun, and at the time of firing, there are many soldiers who do not wear hearing protection devices. Theoretical data show the sound pressure for guns of $9 \mathrm{~mm}=157 \mathrm{~dB}$, riffles of $\mathrm{M}-16=157 \mathrm{~dB}$, grenades $=164 \mathrm{~dB}$, and Howitzer of $105=183 \mathrm{~dB} .{ }^{10,11} \mathrm{~A}$ study in Pusdik Armed Cimahi (2002) showed that 30\% gun firing soldiers are suffered from acoustic trauma (TA). ${ }^{4}$ A study in Magelang showed the number of TAs in the cadets of Police Academy is $12.4 \% .^{5}$

According to Regulation of the Minister of Manpower and Transmigration Number Per.13/Men/X/2011 Year 2011 on Threshold Limit Values for Physical and Chemical Factors in Workplace, it is not allowed for a person to get exposed of noise over $140 \mathrm{dBA}$, although only for a moment.

In addition to causing mechanical damages in the form of tympanic membrane rupture, osicle damages or endolymphatic hydrops, large impulsive sounds (explosions, fires, bombs), when those are exposed to the ear, italso cause metabolic damages in the form of oxidative stress inside the cochlea.

Metabolic damages to oxidative stress are characterized by increased radical oxygen species or radical nitrite species within the cortical organ, resulting in the formation of free radicals such as superoxide anion $\left(\mathrm{O}_{2}^{-}\right)$, hydroxyl radical $\left(\mathrm{OH}^{-}\right.$ ), hypochlorite $\left(\mathrm{OCl}^{-}\right)$and nitric oxide $\left(\mathrm{NO}^{-}\right)$, as well as increased neurotoxicity (glutamate) and ischemia/reperfusion of cochlear blood flow (CBF), subsequently DNA and cell protein damages, and mitochondrial DNA mutations. These mutations are associated with cellular dysfunction, with the final outcome of apoptosis of the outer hair cells in the cochlea.

Other free radical targets are cell membranes, resulting in lipid peroxidation and cell necrosis. Free radical (ROS/RNS) levels in cells cannot be measured, so the main indicator is measuring the level of malondialdehyde (MDA) as a result of lipid peroxidation. MDA levels in peripheral blood describe oxidative stress that occurs in other organs inside the body. The higher the level of MDA is the greater activity of free radicals.

In the cells, ROS/RNS is unstable and cannot be measured. Therefore, the main indicator of cell damages due to oxidative stress is measuring the level of MDA. Blood sampling from peripheral veins to measure MDA levels reflects oxidative stress throughout the body. ${ }^{21}$ A study on soldiers in Turkey stated that there is a significant increase in blood MDA levels before and after a weapon explosion of $138 \mathrm{~dB} .^{6}$

Another indicator of hearing degradation uses an autotoustic emission tool which is sensitive to assess an early damage to cochlear hair cells. A study of young soldiers in France who were observed during 15 days using Distorsion Product Otoacoustic Emissions (DPOAEs) showed a high frequency hearing loss with persistent tinnitus, which occurred in 24 hours after exposured to an automatic machine-gun explosion. . $^{8}$

Neutralization of free radicals (ROS/RNS) in the cochlea is done by endogenous antioxidant enzymes such as glutathione peroxidase (GPx), superoxid dismutase (SOD) and catalase (CAT) working to convert free radicals to nontoxic.

Glutathione peroxidase is an important enzyme that retains cell function and viability. This enzyme has a high activity in vascular stria cells, cortical organs, and mitochondria. In the blood, the enzyme can be measured in erythrocytes (eGPx) which describes intracellular GPx, as well as plasma (pGPx) which describes extracellular GPx. In mammals, GPx levels are equally good in the liver and in the inner ear. Research in Turkey showed an increase in plasma MDA levels, as well as decreased GPx levels and SOD erythrocytes due to noise with an intensity of $104 \mathrm{~dB}$ in employees who worked during $1-7$ years. $^{22}$

Exogenous antioxidants increase the levels of the intra-cell antioxidant enzymes, thus preventing apoptosis/necrosis. Research on experimental animals as well as in humans showed that glutathione peroxidase mimetic (ebselen) has the same cellular mechanism as GPx. Phase-2 ebselen (SPI-1005) clinical research in America had been conducted on 80 marines. Subjects were divided into 4 groups, each group were receiving an oral dose of $200 \mathrm{mg}, 400 \mathrm{mg}, 600 \mathrm{mg}$ in 2 administration, and the last group receiving a placebo for 3-5 days during the firing practice. The study was approved by the World Medical Association Declaration of Helsinki (2004). The results showed that ebselen (SPI-1005) could reduce the hearing loss.

The study to determine the effect of oral ebselen administration as exogenous GPx on GPx and MDA levels of blood and its effect on DPOAEs in a person with TA risk has not been published, especially in Indonesia. Laboratory and audiology examination to determine the initial risks of TA occurrence in soldiers either during firing practice or in periodic examination are still not standardized, as are prevention (with ear protection or drug administration and rehabilitation for TA sufferers have not yet implemented as a hearing conservation program (PKP), especially in the TNI.

\section{MATERIALS AND METHOD}

This study is a quantitative research with a double blind randomized clinical trial placebo controlled pre-and post-test design. Treatment and control groups were drawn from the same affordable populations. Subject selection was done by random permutation blocks. The observations were conducted in double blind. ${ }^{66-70}$ This study has received Ethical 
Approval from Medical Research Ethics Committee of Faculty of Medicine Padjadjaran University Number 41/UN6.C2.1.2/KEPK/PN/2014 dated February 6th, 2014, and research was permited by DanKodiklat TNI-AD Number: B/553/III/2014 dated March 13th, 2014.

The subject of the study was the new enlisted rank students of the Field Artillery Education Center (Pusdik Armed) Kodiklat TNIAD, with initial health data during initial selection showing general physical health status, ear, hearing and labor functions within normal limits, conducting routine firing exercises of 105 Howitzer gun on July 7 - 10 th, 2014 in Batujajar West Java. Subjects were divided into two groups, i.e group I/treatment administered oral mimetic glutathione peroxidase during firing practice and group II/control administered placebo. In accordance with the current standard firing procedures in Pusdik Armed, during the training, the soldiers were not given any medication.

The examination of hearing function of the research subjects used Diagnostic Audiometer AD 229e Interacoustics type AD 229e with serial number 004094, final calibration on January 24th, 2008, while examination of cochlear hair cell function used DPOAE tool MADSEN Capella, made in Denmark calibrated in 2013, Level II Rumkit Audiology Dustira Cimahi. The measurement method of blood MDA levels used TBARS (thiobarbiturate acid reactive substance) method, while the measurement of blood GPx levels used colorimetric assay method from Oxford Bimedical Research FR 17. The working principle was the indirect examination of c-GPx and GSSG activities.

For the workings and data collection techniques of this study, determination of research subjects in health clinics Pusdik Armed were initially conducted on day D-2. Each subject was then given some explanations about the intent and purpose of the study. Explanation was done by ignoring the rank level. The subjects were free for not following the study. After obtaining subjects' approval, medical history and otoscopy were done by the researchers.

On the day D-1 day, all subjects were subjected to pure tone audiometry and DPOAE, routine blood and urine, SGOT, SGPT, Ureum, Creatinine, Electrocardiography (ECG), GPx examination and 1st blood MDA (PRE). The examination was done in Division of ENT and Pathology Clinic Dustira Hospital. The allocation of subjects into the treatment and control was done by random permutation blocks to obtain a balanced number of subjects. The researchers did not know which one was selected as the treatment group or the control group.

On day D, morning at $04.30 \mathrm{WIB}$, the treatment group was given a capsule containing $200 \mathrm{mg}$ glutathione peroxidase mimetic (ebselen, SPI 1005) orally, while the control group was given a capsule containing $200 \mathrm{mg}$ sucrose powder (placebo). The capsule administration to the subjects who had been randomized by permutation blocks was performed by Pusdik Armed physicians randomly without knowing the stuffing of the capsule as well as the subjects of the treatment or control group.

On day $\mathrm{D}$ and $\mathrm{D}+1$, starting at 09.00 , the entire research groups carried out the 105 Howitzer gun firing practice. On day $\mathrm{D}$, the subject served as a firer was beside the gun, and on day $\mathrm{D}+1$, the subject served as an observer at the target location with a distance of approximately 500 meters from the fall of the bullet.

On day D+2, all subjects were subjected to be checked in pure tone audiometry and DPOAE, routine blood and urine, SGOT, SGPT, Ureum, Creatinine, Electrocardiography (ECG), GPx examination and 2nd blood MDA (POST). The results were then submitted to the researchers, continued by data processing.

\section{RESULTS AND DISCUSSION}

\section{a. Results}

For the characteristics of the subjects, the average age in the treatment group was 20.7 years $(\mathrm{SD}=0.90)$ whereas in the control group was 20.8 years $(\mathrm{SD}=0.90)$, the age range of the two groups was $19-22$ years.

The characteristics of smoking habits in both subjects to determine that confounding variables were negligible are shown in Table 1

Table 1 Characteristics of Subjects by Smoking Habits

\begin{tabular}{cccc}
\hline Variable & Smoking (+) & Smoking (-) & p $^{*}$ \\
\hline Treatment Group $(\mathrm{n}=17)$ & 16 & 1 &., 0 \\
\hline Control Group $(\mathrm{n}=17)$ & 16 & 1 & \\
\hline Total $(\mathrm{n}=34)$ & 32 & 2 \\
\hline
\end{tabular}

Description *) : based on Exact Fisher Test

The statistical calculation in Table 1 using Exact Fisher test shows $\mathrm{p}=1.0$, which means there is homogeneity of smoking habit variable in both groups, thus confounding variable (smoking history) can be ignored.

\section{Measurement of Sound Pressure Level of Gun and Noise Dose (\%dose)}

Initial data based on the theory, the sound pressure level of 105 Howitzer gun was $183 \mathrm{dBA}$ while the measurement on the same gun in Pusdik Armed Kodiklat TNI-AD 2002 was 173.4 dBA with a frequency of 0.09 seconds. Currently, the sound pressure level of 105 Howitzer gun is $148.6 \mathrm{dBA}$ with decaying time up to $60 \mathrm{dBA}$ for about 2 seconds, as well as the noise dose received by the soldier at 1 meter beside the gun of $481.43 \%-2858.35 \%$ (NIOSH) . 
The Results of Blood, Routine Urine, Hepatic and Renal Function Examination as well as EKG

Blood sampling and cardiac function examination in both groups were performed before and after the firing practice. Routine blood, routine urine, hepatic and renal function and electrocardiography (EKG) examination were done to evaluate the side effects of ebeselen SPI 1005 and placebo that had been given before. In both groups, the overall examination results were within normal limits, both before and after firing practice.

\section{The Results of Erythrocyte and Plasma GPx Examination in Both Groups}

After carrying out the firing, blood sampling was done to the two groups to assess the levels of erythrocyte and plasma GPx, and the results can be seen in Table 2 to 5 below.

Table 2 The Comparison of Difference in Erythrocyte GPx Levels in Both Groups Before and After Treatment
Erythrocyte GPx
Group
P value ${ }^{*}$
$(\mathbf{n m o l} / \mathbf{m i n} / \mathbf{m l})$

\begin{tabular}{lccc}
\cline { 2 - 3 } & Control $(\mathbf{n}=\mathbf{1 7})$ & Treatment $(\mathbf{n}=\mathbf{1 7})$ & \\
\hline Mean ${ }^{* *)}$ & 41.5 & 58.8 & \\
Median & -3.82 & 16.55 & 0.049 \\
Standard Deviation & $215 ., 67$ & 246.08 &
\end{tabular}

\footnotetext{
Description : ${ }^{*)}$ based on Mann-Whitney test

${ }^{* *}$ Mean Difference (pre-post)
}

Table 2 shows mean after treatment (Ebternen SPI 1005 1x200 mg/day orally), erythrocyte GPx values increase compared before treatment, and the result is statistically significant $(\mathrm{p}<0.05)$. Table 3 shows the comparative increase and decrease in erythrocyte GPx levels in both groups after firing the 105 Howitzer gun

Table 3 The Comparison of Increase and Decrease in Erythrocyte GPx Levels in Both Groups after the Treatment

\begin{tabular}{|c|c|c|c|c|c|c|}
\hline \multirow{3}{*}{ Group } & \multicolumn{4}{|c|}{ Erythrocyte GPx (nmol/min/ml) } & \multirow{3}{*}{$\mathbf{p}^{*}$} & \multirow{3}{*}{ NNT $\left.(95 \% \text { CI })^{* *}\right)$} \\
\hline & \multicolumn{2}{|c|}{ Increase } & \multicolumn{2}{|c|}{ Decrease } & & \\
\hline & $\mathrm{N}$ & $\%$ & $\mathrm{n}$ & $\%$ & & \\
\hline Treatment $(n=17)$ & 14 & 82.4 & 3 & 17.6 & & \\
\hline Control (n=17) & 5 & 29.4 & 12 & 70.6 & 0.004 & $\begin{array}{c}1.889 \\
(1.159-3.016)\end{array}$ \\
\hline Amount $(n=34)$ & 19 & 55.9 & 15 & 44.1 & & \\
\hline
\end{tabular}

Description: *) based on Logistic Regression test

${ }^{* * *)}$ Number Needed to Treat with $95 \%$ Confidential Interval

Table 3 shows that the treatment group has NNT $(95 \% \mathrm{CI})=1.889(1.159-3.016)$, compared with the control group, which is statistically significant $(\mathrm{p}<0.05)$. This means that the administration of Ebselen SPI $10051 \times 200 \mathrm{mg} / \mathrm{day}$ orall in 2 soldiers will prevent 1 soldier (50\%) from the risk of decrease in erythrocyte GPx levels due to 105 Howitzer gun explosion. Table 4 shows the comparison of increases and decreases in plasma GPx levels in both groups after firing the 105 Howitzer gun.

Table 4 The Comparison of Difference in Erythrocyte GPx Levels in Both Groups after the Treatment

\begin{tabular}{lccc}
\hline \multicolumn{1}{c}{$\begin{array}{c}\text { Plasma GPx } \\
(\mathbf{n m o l} / \mathbf{m i n} / \mathbf{m l})\end{array}$} & Group & P value*) $^{*}$ \\
\cline { 2 - 3 } & $\begin{array}{c}\text { Control } \\
(\mathbf{n = 1 7 )}\end{array}$ & $\begin{array}{c}\text { Treatment } \\
(\mathbf{n = 1 7})\end{array}$ & \\
\hline Mean & -4.05 & 1.05 & \\
Median & -5.09 & 7.64 & 0.006 \\
Standard Deviation & 7.37 & 15.07 & \\
\hline
\end{tabular}

Description : ${ }^{*}$ based on $\mathrm{T}$ - Independent test 
Table 4 from the obtained mean, found that plasma GPx in the treatment group after Ebselen SPI 1005 1x200 mg/day orally increases compared with the previous, whereas in the control group, the mean plasma after placebo decreases, which is statistically significant $(\mathrm{p}<0.05)$.

Table 5 shows a comparison of the increase and decrease in plasma GPx levels in both groups of soldiers after being administered SPI 1005 1x200 mg orally in the treatment group and placebo in the control group, and after the 105 Howitzer gun practice, as follows:

Table 5 The Comparison of Increase and Decrease in Plasma GPx Levels in Both Groups after the Treatment

\begin{tabular}{|c|c|c|c|c|c|c|}
\hline \multirow{3}{*}{ Group } & \multicolumn{4}{|c|}{ Plasma GPx (nmol/min/ml) } & \multirow{3}{*}{$\mathbf{p}^{*)}$} & \multirow{3}{*}{ NNT $(95 \%$ CI) } \\
\hline & \multicolumn{2}{|c|}{ Increase } & \multicolumn{2}{|c|}{ Decrease } & & \\
\hline & $\mathbf{N}$ & $\%$ & $\mathbf{n}$ & $\%$ & & \\
\hline Treatment $(n=17)$ & 15 & 88.2 & 2 & 11.8 & \multirow{2}{*}{$<0.001$} & \multirow{2}{*}{$1.417(0.970-1.775)$} \\
\hline Control ( $\mathrm{n}=17)$ & 3 & 17.6 & 14 & 82.4 & & \\
\hline Amount $(n=34)$ & 18 & 52.9 & 16 & 47.1 & & \\
\hline
\end{tabular}

Description: *) based on Logistic Regression test

${ }^{* * *}$ Number Needed to Treat with $95 \%$ Confidential Interval

Table 5 shows that the treatment group has NNT $(95 \% \mathrm{CI})=35(95 \% \mathrm{CI}=1.417(0.970-1.775)$, compared with the control group which is statistically significant ( $\mathrm{p}<0.001)$. It means that Ebselen SPI $10051 \times 200 \mathrm{mg} / \mathrm{Day}$ orally on 3 soldiers will prevent 2 soldiers (70\%)from the risk of decreasing plasma GPx levels due to the 105 Howitzer explosion.

The Results of Erythrocyte and Plasma MDA Level Examination from Both Groups

The results of erythrocyte and plasma MDA measurements in both treatment groups are presented in Table 6 to Table 9 below.

Table 6 The Comparison of Difference in Erythrocyte MDA Levels in Both Groups Before and After Treatment

\begin{tabular}{|c|c|c|c|}
\hline \multirow[t]{2}{*}{ Erythrocyte MDA (mmol/L) } & \multicolumn{2}{|c|}{ Group } & \multirow{2}{*}{ P value ${ }^{*)}$} \\
\hline & $\begin{array}{c}\text { Control } \\
(n=17)\end{array}$ & $\begin{array}{c}\text { Treatment } \\
\quad(n=17)\end{array}$ & \\
\hline Mean & -0.48 & -10.79 & \\
\hline Median & -5.46 & 3.36 & 0.002 \\
\hline Standard Deviation & 11.97 & 14.83 & \\
\hline
\end{tabular}

Description : ${ }^{*}$ based on $\mathrm{T}$ - Independent test

From table 6, when viewed from the mean obtained, it found that the mean erythrocyte MDA values in the treatment group after Ebselen SPI 1005 1x200 mg/day peroral decrease compared with before the drug administration, and this is statistically significant $(\mathrm{p}<0.05)$.

Table 7 shows the comparison of erythrocyte MDA levels in both groups after the groups were being given Ebselen SPI 1005 1x200 mg orally (treatment group) and placebo (control group), and after carrying out the 105 Howitzer firing practice.

Table 7 The Comparison of Increase and Decrease in Erythrocyte MDA levels in Both Groups after the Treatment

\begin{tabular}{|c|c|c|c|c|c|c|}
\hline \multirow{3}{*}{ Group } & \multicolumn{4}{|c|}{ Erythrocyte MDA (mmol/L) } & \multirow{3}{*}{$\mathbf{p}^{*)}$} & \multirow{3}{*}{ NNT (95\% CI) } \\
\hline & \multicolumn{2}{|c|}{ Increase } & \multicolumn{2}{|c|}{ Decrease } & & \\
\hline & $\mathbf{N}$ & $\%$ & $\mathbf{N}$ & $\%$ & & \\
\hline Treatment $(\mathrm{n}=17)$ & 17 & 100 & 0 & 0 & \multirow{2}{*}{$<0.001$} & \multirow{2}{*}{$1.417(0.994-1.836)$} \\
\hline Control (n=17) & 5 & 29. & 12 & 470.6 & & \\
\hline Amount $(\mathrm{n}=34)$ & 22 & 64. & 12 & 735.3 & & \\
\hline
\end{tabular}

Description : ${ }^{*}$ based on Exact Fisher Test 
Table 7 shows that the treatment group has NNT $(95 \% \mathrm{CI})=35(95 \% \mathrm{CI}=1.417(0.994-1.836)$, compared with the control group which is statistically significant ( $\mathrm{p}<0.001)$. It means that Ebselen SPI $10051 \times 200 \mathrm{mg} /$ day orally on 3 soldiers will prevent $2(70 \%)$ soldiers from the risk of increased erythrocyte MDA levels of due to the 105 Howitzer gun explosion.

Table 8 The Comparison of Difference in Plasma MDA Levels in Both Groups Before and After Treatment

\begin{tabular}{lccc}
\hline \multirow{2}{*}{ Plasma MDA (mmol/L) } & \multicolumn{2}{c}{ Group } & \multirow{2}{*}{ P value*) } \\
\cline { 2 - 3 } & $\begin{array}{c}\text { Control } \\
(\mathbf{n = 1 7})\end{array}$ & $\begin{array}{c}\text { Treatment } \\
(\mathbf{n = 1 7})\end{array}$ & \\
\hline Mean & -3.35 & -22.52 & 0.02 \\
Median & 3.36 & -10.07 & \\
Standard Deviation & 14.83 & 37.58 & \\
\hline
\end{tabular}

Description : *) based on Mann-Whitney test

From table 8, when viewed from the obtained mean, it found that the mean plasma MDA values in treatment group after being given Ebselen SPI 1005 1x200 mg orally decrease compared with before the drug administration.

Table 4.9 shows the comparison of plasma MDA levels in both groups of soldiers after being given SPI $10051 \times 200 \mathrm{mg}$ orally in the treatment group and placebo in the control group, and after carrying out the 105 Howitzer firing practice, presented as follows:

Table 9 The Comparison of Increase and Decrease in Plasma MDA levels in Both Groups after the Treatment

\begin{tabular}{|c|c|c|c|c|c|c|}
\hline \multirow{3}{*}{ Group } & \multicolumn{4}{|c|}{ Plasma MDA (mmol/L) } & \multirow{3}{*}{$\mathbf{p}^{*}$} & \multirow{3}{*}{ NNT $(95 \%$ CI $)$} \\
\hline & \multicolumn{2}{|c|}{ Increase } & \multicolumn{2}{|c|}{ Decrease } & & \\
\hline & $\mathbf{N}$ & $\%$ & $\mathbf{N}$ & $\%$ & & \\
\hline Treatment $(\mathrm{n}=17)$ & 16 & 94. & 1 & 15.9 & \multirow{2}{*}{0.01} & \multirow{2}{*}{$2.125(1.29-3.904)$} \\
\hline Control (n=17) & 8 & 47.1 & 9 & 52.9 & & \\
\hline Amount $(n=34)$ & 24 & 70.6 & 10 & 29.4 & & \\
\hline
\end{tabular}

Description $:{ }^{*}$ based on Logistic Regression test

From Table 4.9, it is seen that treatment group has NNT $(95 \% \mathrm{CI})=2.125(1.29-3.904)$, compared to control group, which is statistically significant $(\mathrm{p}<0.05)$. This means that the administration of SPI $10051 \times 200 \mathrm{mg} / \mathrm{day}$ orally to 2 soldiers will prevent 1 soldier (50\%) from the risk of increasing plasma MDA levels due to 105 Howitzer gun explosion.

To find the correlation strength between GPx levels and blood MDA levels in both groups after being given Ebselen/SPI 1005 1x200 mg orally and carrying out the gun firing practice, Pearson correlation test was performed. The results showed that erythrocyte GPx levels and plasma MDA levels have a very strong correlation and are statistically significant ( $p<$ 0.001). However, the direction of correlation is negative, it means the higher the erythrocyte GPx levels is the lower the plasma MDA levels, and this is not a mere coincidence.

\section{The Results of Pure Tone Audiometry}

The results of a pure tone audiometry showed that the number of soldiers who experienced Acoustic Trauma (TA) is 4 out of 17 people in the control group who were given a placebo (according to the standard procedure of firing guns), while there is no TA the treatment group given Ebselen/SPI 1005, so that when the firing practice is carried out with the old procedure (without ear protection and without taking any drug), the risk of TA on the soldier is $23.5 \%$ as shown in Table 4.10 . 
Table 10 The Comparison of TA, Hearing Loss Complaints (KGD) and Tinnitus in Both Groups after Firing

\begin{tabular}{|c|c|c|c|c|c|c|}
\hline Research Group & $\begin{array}{l}\text { TA } \\
(+)\end{array}$ & $\begin{array}{c}\text { TA } \\
(-)\end{array}$ & $\begin{array}{c}\text { Tinnitus } \\
(+)\end{array}$ & $\begin{array}{c}\text { Tinnitus } \\
(-)\end{array}$ & $\underset{(+)}{\text { KGD }}$ & $\begin{array}{c}\text { KGD } \\
(-)\end{array}$ \\
\hline $\begin{array}{l}\text { Control group }(\mathrm{P}) \\
\mathrm{n}=17\end{array}$ & $\begin{array}{c}4 \\
(23.5 \% \\
)\end{array}$ & $\begin{array}{c}13 \\
(76.5 \%)\end{array}$ & $\begin{array}{c}1 \\
(5.9 \%)\end{array}$ & $\begin{array}{c}16 \\
(94.1 \%)\end{array}$ & $\begin{array}{c}1 \\
(5.9 \%)\end{array}$ & $\begin{array}{c}16 \\
(94.1 \%)\end{array}$ \\
\hline $\begin{array}{c}\text { Treatment group } \\
\begin{array}{c}(\mathrm{G}) \\
\mathrm{n}=17\end{array}\end{array}$ & $\begin{array}{c}0 \\
(0 \%)\end{array}$ & $\begin{array}{c}17 \\
(100 \%)\end{array}$ & $\begin{array}{c}0 \\
(0 \%)\end{array}$ & $\begin{array}{c}17 \\
(100 \%)\end{array}$ & $\begin{array}{c}0 \\
(0 \%)\end{array}$ & $\begin{array}{c}17 \\
(100 \%)\end{array}$ \\
\hline P value ${ }^{*)}$ & \multicolumn{2}{|c|}{0.049} & \multicolumn{2}{|c|}{0.5} & \multicolumn{2}{|c|}{0.5} \\
\hline
\end{tabular}

Description : ${ }^{*}$ based on Exact Fisher Test

The statistical calculation in Table 10 shows the comparison of TA, hearing loss complaints (KGD) and Tinnitus in both groups using the Exact Fisher test. Based on the results, the number of TA is $23.5 \%$ in the control group, which is statistically significant $(\mathrm{p}<0.05)$, while the hearing loss complaints and tinnitus are not statistically significant $(\mathrm{p}>0.05)$.

\section{The Results of Otoacoustic Emissions (DPOAEs)}

From Table 11, it can be seen that in the treatment group (given Ebselen/SPI 1005 1x200 mg orally), all (100\%) have normal otoacoustic emission values (pass) and the control group (given placebo) has normal emission values (pass) of $52.9 \%$, meaning that the proportion of normal (pass) acoustic emission values (DPOAEs) in the treatment group is greater than the control group.

Proportionally, there is a correlation between Ebselen/SPI 1005 1x200 mg orally with normal acoustic emission values (pass), but this correlation must be tested statistically, and the result is very significant $(\mathrm{p}=0.01)$, so the correlation between Ebselen/SPI 1005 1x200 mg orally with normal acoustic emission values (DPOAEs) (pass) is very significant

Table 11 The Results of DPOAE Examination in Both Groups after Implementing 105 Howitzer Gun Firing

\begin{tabular}{|c|c|c|c|c|c|c|}
\hline \multirow{3}{*}{ Research groups } & \multicolumn{4}{|c|}{$\begin{array}{l}\text { Results of otoacoustic emissions } \\
\text { (DPOAEs) }\end{array}$} & \multirow{3}{*}{$\begin{array}{c}\text { Risk of DPOAE } \\
\text { abnormalities } \\
(\text { Refer })\end{array}$} & \multirow{3}{*}{$\mathbf{p}^{*)}$} \\
\hline & \multicolumn{2}{|c|}{ Pass } & \multicolumn{2}{|c|}{ Refer } & & \\
\hline & $\mathbf{n}$ & $\%$ & $\mathbf{n}$ & $\%$ & & \\
\hline $\begin{array}{l}\text { Control group }(\mathrm{P}) \\
\mathrm{n}=17\end{array}$ & 17 & 100 & 0 & 0 & $0 / 17$ & \\
\hline $\begin{array}{l}\text { Treatment group }(\mathrm{G}) \\
\qquad \mathrm{n}=17\end{array}$ & 9 & 52.9 & 8 & 47.1 & $8 / 17$ & \\
\hline P value $\left.{ }^{*}\right)$ & 26 & 76.5 & 8 & 23.5 & & \\
\hline
\end{tabular}

Description : ${ }^{*}$ based on Exact Fisher Test

From the data of risk of DPOAE abnormalities in the two groups, the Absolute Risk Reduction (ARR) can be calculated, i.e:

- $\quad \operatorname{ARR}=8 / 17-0 / 17=8 / 17$. From ARR, NNT can be calculated, i.e

- $\quad$ NNT (Number Needed to Treat $)=1 / \mathrm{ARR}=17 / 8=2.125$. With Confidential Interval $(\mathrm{CI}) 95 \%=1.335-3.987$

The results of NNT $=2,125$ means that out of 2 gun firing soldiers were treated, i.e SPI $10051 \times 200 \mathrm{mg} / \mathrm{day}$ peroral, there is only 1 soldier (50\%) spared from the risk of TA (result of DPOAEs becomes refer) by the 105 Howitzer gun explosion.

\section{b. Discussion}

The study on the risk of acoustic trauma to personnel in the military ranks are using the 105 Howitzer gun source of exposure is almost never published in Indonesia or internationally.

The selection of subjects of new enlisted rank students is due to the organizational structure of the field artillery firer, the towing rope driver is a soldier with the enlisted rank. The top commander is a non-commissioned officer, and an officer is the leader of several guns. Thus in an artillery battle, it is the soldiers with the enlisted rank who most often exposed the impulsive noise of the gun explosion.

Referring to preliminary data, the sound pressure level at 1 meter apart from the gun is $148.6 \mathrm{dBA}$, with the decaying time required after the explosion is up to $60 \mathrm{dBA}$ in the range of 2 seconds. It is different from the theory that the sound pressure level of 105 Howitzer gun is $183 \mathrm{dBA}$. In the study with a similar type of gun (2002), the sound pressure level is 
173.4 dBA. The difference is due to the stuffing of the gunpowder used in the current firing practice (in 2014) as much as 6 of the maximum 10 stuffing, while the 2002 study used 7 of 10 stuffing, and most likely obtained from the theory (183 dBA) using the maximum stuffing.

According to NIOSH (2002) on noise impulses from weapon explosion, the calculation of the number of allowed explosions/day uses the formula:

$\mathrm{N}=10^{\wedge}((140-\mathrm{PI}) / 10)$; where $\mathrm{PI}=\mathrm{L}$ peak - attenuation of ear protection devices.

So according to the NIOSH, none of the firers can fire the gun safely without ear protection devices.

According to Regulation of the Minister of Manpower and Transmigration Number Per.13/Men/X/2011 Year 2011 Threshold Limit Values for Physical and Chemical Factors in Workplace, it is not allowed a person to be exposed to noise over $140 \mathrm{dBA}$, although for a moment.

The Government's policy to implement the hearing conservation program in the industrial sector is clear with the existence of health institutions and various laws and policies, but in the ranks of the TNI, working environment with the risk of occupational deafness still does not exist. In fact, the army and in the US Department of Defense already have a clear hearing conservation organization and program.

In the Army of America, the implementation of the hearing conservation program has gone well. They have run the program thoroughly, i.e noise hazard identification, engineering controle, hearing protection, monitoring audiometry, health administration, inforcement and program evaluation.

Whereas in the Indonesian Army ranks, the admission of potential soldiers and periodic health examination on soldiers using audiometric examination is still not evenly distributed, while the use of otoacoustic emission diagnostic tool has not been used at all, as well as the installation procedure of hearing aids for soldiers with hearing loss is still unclear. Thus it has not been fully supported.

Scientific research on the effect of administration of Ebselen SPI 1005 orally has been correlated with blood GPx and MDA levels, as well as the results of DPOAEs in humans, according to the investigation, it has not been published in national and even international literature, and this is a recent study in Indonesia.

Glutathione peroxidase (GPx) is a family of intra- and extra-cellular enzymes. In mammals, the concentration of glutathione peroxidase is similar between inner ear and in tissues/other organs.

There is a significant increase in blood GPx levels, both erythrocytes and plasma in the treatment group, as well as an increase in the number of treatment group subjects after being given Ebselen/SPI 1005 1x200 mg/day orally, compared with the control group. It is in accordance with the theory that exogenous antioxidant enzyme administration increases levels of enzymes in the blood. Of the 6 (six) types of GPx in the blood, GPx1/e-Gpx (erythrocyte GPx) can be identified as an overview of intracellular GPx and Gpx3/p-GPx (plasma GPx) as an overview of extracellular GPx

Ebselen/SPI 1005 is also a seleno-organic compound with similar activity to GPx enzyme, so in the treatment group despite oxidative stress due to the 105 Howitzer gun explosion, the percentage of blood GPx levels (both erythrocyte and plasma) and the number of subjects remain significantly higher compared with the control group.

Explosion noise from the 105 Howitzer gun to the two groups also showed that in the control group were only given a placebo, there is a significant decrease in blood GPx levels (either erythrocytes or plasma), and the number of subjects significantly. This is in accordance with the theory that oxidative stress in the cochlea will lead to decreased levels of intracellular antioxidant enzymes, which ultimately result in apoptosis of cochlear hair cells

As a comparison, a study in Turkey has decreased levels of erythrocyte glutathione peroxidase (GPx) and superoxid dismutase (SOD) and increased plasma malondialdehyde (MDA) levels, due to noise intensity of 104 dB in employees who worked for $1-7$ years.

Other studies in the United States to the experimental animals F-344 rat were given an exposure to noise of 113 and $115 \mathrm{~dB}$ for 4 hours and given ebselen $4 \mathrm{mg} / \mathrm{kgBB}$ orally before and immediately after the exposure to noise, then measured the GPx (GPx1, GPx2, GPx3, GPx4) levels, the results showed an increase in GPx1 in vascular stria, decreased vascular stria udem and decreased outer hair cell damages at 5 hours after exposure to noise.

When compared to the results with other studies abroad, theoretically there is a conformity that the noise will decrease levels of endogenous antioxidant enzymes and the administration of exogenous antioxidants will increase levels of endogenous antioxidant enzymes and reduce damage to cochlear hair cells due to oxidative stress.

Malondialdehyde (MDA) is a lipid peroxidation product due to free radicals and is used as an indicator of cell damage due to oxidative stress, so that measurement of blood MDA levels reflects oxidative stress throughout the body. There is a significant decrease in blood MDA levels, both erythrocytes and plasma in the treatment group, as well as decrease in the subjects of the treatment group versus the control group, according to the theory.

Ebselen/SPI 1005 is an antioxidant, with anti-inflammatory and cytoprotective effects that effectively decrease hydroperoxide $\left(\mathrm{H}_{2} \mathrm{O} 2\right)$ in biomembrane and lipoprotein, thus inhibiting oxidative stress in the cochlea was caused by the 105 Howitzer gun explosion.

Decreased oxidative stress is reflected by decreased blood MDA levels (both erythrocytes and plasma). Lower MDA levels show free radical suppression, due to higher antioxidants.

Increased percentage of MDA levels (erythrocytes and plasma), as well as the number of subjects significantly in the control group (given only placebo) after the firing practice is also in accordance with the theory. 
Exposure to noise of gun explosion results in increased free radical (oxidative stress) resulting in damage to enzyme, protein, lipid, and DNA structure systems in the form of lipid peroxidation as well as activation of c-JNK and p38MAPK pathways, cytochrome-c release which will trigger caspase 2,3,8 and 9 with apoptosis of cochlear hair cells.

Increased free radical in cochlea is reflected by the increased blood MDA levels. Several studies have shown the increased blood MDA levels due to exposure to noise.

A study of soldiers in Turkey stated that there is a significant increase in blood malondialdehide (MDA) levels before and after the $138 \mathrm{~dB}$ gun explosion. Another study in Turkey showed 127 noise-exposed factory workers, using spectrophotometric methods showed the increased MDA levels and decreased blood SOD and CAT levels significantly than the control group.

Based on the theory, the higher MDA levels show the greater the activity of free radicals. Conversely, low MDA levels indicate free radical suppression, including with the presence of higher antioxidants. Blood sampling from peripheral veins to measure plasma MDA levels reflects oxidative stress throughout the body.

On the lateral wall of the cochlea, vascular stria and spiral ligament endothelial cells mostly contain mitochondria with active metabolism. In this area, GPx is a major intracellular antioxidant. In human blood, GPx activity can be measured from GPx1/cGPx/eGPx as an overview of intracellular and mitochondrial GPx.

Glutathione peroxidase mimetic (ebselen) is a potent radical suppressor (ROS scavenger) to polyunsaturated fatty acid (PUFA), which is also a dangerous radical in biological systems. These peroxide results would have a direct effect on cell membrane damage, such as changing fluidity, crosslinking, structure, and membrane function, and cell necrosis

Above the two arguments, it is rational if there is a strong and meaningful correlation between increasing erythrocyte GPx levels and decreasing plasma MDA levels after Ebselen SPI 1005 1x200 mg/day orally.

Based on the results of pure tone audiometric examination of control group subjects after firing practice, $23.5 \%$ of soldiers significantly experience TA. The results of otoacoustic emission (DPOAEs) even significantly show that $47.1 \%$ of soldiers in the control group have abnormal results (refer) or early damage to cochlear hair cells.

A study of young soldiers in France who were observed 15 days with Distorsion Product Otoacoustic Emissions (DPOAEs) showed a high frequency hearing loss with persistent tinnitus, which occurred 24 hours after exposure to an automatic machine-gun explosion.

The results of this study when associated with other studies abroad also has a conformity and is accordance with the theory that the TA belonging to the occupational deafness group has a typical picture on the audiogram, namely the sensorineural deaf picture with a notch at a frequency of $4000 \mathrm{~Hz}$, and this is also in accordance with the Equal Loudness Contour graphs of each frequency, and the examination using DPOAEs generally gives abnormal results (refer), accompanied by tinnitus complaints.

The weakest point in the human ear, of all frequencies, is present at a frequency of $4000 \mathrm{~Hz}$, since the human ear response to noise is not the same at all frequencies, i.e high and medium frequencies are more sensitive than low frequencies.

The cochlear basalt part (closest to the foramen ovale) receives a high-frequency sound. Cochlear damage due to high frequency and intensity is centered at a frequency of $4000 \mathrm{~Hz}$ where this state corresponds to the greatest vibration of the basilar membrane and the cortical organ.

Hair cells that have the greatest amplitude are present in about $10 \mathrm{~mm}$ of the foramen ovale and receive the greatest energy at the exposure to noise, so that the part will be easily injured in the exposure of noise. These are referred to as ' $4000 \mathrm{~Hz}$ receptors' and because their connection to nerve fibers, these also often referred to as ' $4000 \mathrm{~Hz}$ nerve fiber' and this is a minicular locus in the cortical organs.

In the treatment group given Ebselen SPI 1005 1x200 mg/day orally, all (100\%) subjects have normal (pass) DPOAE results after the 105 Howitzer gun explosion, since Ebselen has the same activity as GPx. This study has selected dose of Ebselen SPI 1005 for 1x $200 \mathrm{mg}$ /day orally. Despite the low dose, it is also effective as an autoprotector due to exposure of high impulsive noise.

GPx1 enzyme is one family of glutathione peroxidase enzymes that serve to detoxify peroxidase in the cells. Ebselen at low concentrations inhibites some inflammatory enzymes such as lipoxygenase, NO synthase, NADPH, oxidase, protein kinase- $\mathrm{C}$ and $\mathrm{H}^{+} / \mathrm{K}^{+}$-ATPase. The inhibitory process occurs at the cellular level and this is the anti-inflammatory effect of ebselen.

A study in the United States showed that ebselene (SPI-1005) effectively at low doses (8 - $10 \mathrm{mg} / \mathrm{kgBW} / \mathrm{day}) \mathrm{may}$ decrease temporary treshold shift (TTS), permanent treshold shift (PTS) and loss of outer hair cells in the experimental animals (rats and marmots).

Phase-2 ebselen (SPI-1005) clinical research in America had been conducted on 80 marines divided into 4 groups, each group were receiving an oral dose of $200 \mathrm{mg}, 400 \mathrm{mg}, 600 \mathrm{mg}$ in 2 administrations, and the last group was receiving a placebo for 3-5 days during the firing practice. The results showed that ebselen (SPI-1005) could reduce the hearing loss.

When compared with research in the United States, the results of this study have conformity and prove that SPI 1005 is a potent exogenous antioxidant to neutralize free radicals due to exposure to noise and able to prevent damage to cochlear hair cells, so that there is no TA. 


\section{a. Conclusion}

\section{CONCLUSION AND SUGGESTION}

The present study concludes that the administration of glutathione peroxidase mimetic, Ebselen SPI 1005 1x200 mg/day orally in soldiers at risk of acoustic trauma during the 105 Howitzer gun firing practic, increases blood GPx levels, decreases blood MDA levels, and results in normal otoacoustic emission values.

Another conclusion is the sound pressure level of 105 Howitzer gun with 6 of 10 stuffing of 148.6 dBA, with decaying time up to $60 \mathrm{dBa}$ for about 2 seconds, as well as the dose of noise (\%dose) 1 meter apart from the $481.43 \%-2858.35 \%$ (NIOSH).

The pure tone audiometry test results show the number of TAs in 105 Howitzer gun firing soldiers of $23.5 \%$, which means there has been a hearing loss, whereas DPOAEs show abnormal results (Refer) of $47.1 \%$, which means there has been an early damage to the cochlear hair cell, although there has not been a TA. The results of NNT calculation on the solders given Ebselen SPI 1005 1x200 mg/day orally are associated with GPx and MDA blood levels and DPOAE values range from 1.4 to 2.1, which means that the administration of SPI 1005 is useful to avoid $50 \%-70 \%$ of other soldiers at risk of TA due to the 105 Howitzer gun explosion.

\section{b. Suggestion}

Variations of research subjects, dosage, and duration of antioxidants (Ebselen SPI 1005) are required, in order to maximize the benefits obtained. Monitoring and evaluation of hearing function are not only use a pure tone audiometry, but also use more sensitive otoacoustic emissions (DPOAEs) as indicates an early detection of cochlear cell damage, not only before and after treatment, but also the evaluation intervals after longer firing practice to see if the hearing loss is permanent or temporary.

Further research is required for pharmacological/chemical modification of Ebselen SPI 1005 preparation form to other inexpensive preparation forms, in order to be mass produced and can be used as a standard preventive drug for TA.

It is time for the TNI to establish a Hearing Conservation Program (PKP) with real and sustainable implementation for the personnels at risk of occupational deafness.

\section{Acknowledgment}

My deepest acknowledgment I give to Prof. Dr. Budi Setiabudiawan dr., Sp.A (K)., M.Kes. as a coordinator in Magister School of Medical Faculty in Padjajaran University. To the honorable of Head Promotor Team Prof. Dr. H.M. Thaufiq S. Boesoirie, dr., MS., Sp.THT-KL (K) and the members of Promotor Team, Prof. Dr. Ida Parwati, dr., Sp.PK (K), PhD and also Prof., Dr., Herri Sastramihardja, dr., Sp.FK (K). To the honorable Oponen Expert Team, Prof., Dr., Johanes C. Mose, dr., Sp.OG (K), Prof. Jenny Bashiruddin, dr., Sp.THT-KL (K) and Prof. Dr. Iwin Sumarwan, dr., Sp.THT-KL (K), KRA, KAI, also the representative professor, Prof., Dr., Nanan Sekarwan, dr., SP.A (K), MARS, for gave the writers supports, helps, corrections and also suggestion in this dissertation.

\section{REFERERENCES}

1. WHO Regional Office SEARO. State of hearing and ear care in South East Asia Region. 2004.

2. Brian K, Drug may help troops battle combat - related hearing loss, http : // newsok.com/drug-may-help-troops-battlecombat-related-hearing-lossbr. Published : July 6, 2008.

3. Lynch ED and Kill J. Compounds for the prevention and treatment of noise induce hearing loss. Drug Discovery Today (DDT).www.drugdiscoverytoday.com. 2005;10;19.(1291-1298).

4. Sasongko S, Trauma akustik yang disebabkan ledakan meriam pada prajurit di Pusat Pendidikan Artileri Medan Kodiklat TNI-AD Cimahi Jawa-Barat, Tesis PPCD FK Unpad, Bandung, 2003.

5. Budiyanto A. Trauma akustik akibat latihan menembak pada Taruna Akpol Semarang. Tesis PPDS I FK Undip. Semarang. 2003.

6. Cetin B, Cekin E, Cincik H, Gungor A.. Relationship between acoustic trauma and serum level of vitamin B12, Folic acid, Zinc, Magnesium and MDA. Mediterr. J. Otol. 2008, 4.(3).

7. SPC.OPAL HOOD, $5^{\text {th }}$ Mobile Public Affairs Detachment. Hearing loss No. 1 Diagnosis for US soldiers in Afghanistan. Hearing Health Magazine, http : //www. drf. org / magazine / 38/winter+2010+issue/article/2. December $\underline{29}, 2009$.

8. Nottet, J.-B.; Brossard, N.; Suc, B.; Job, A. (2005) Distortion Products Otoacoustic Emissions as Markers of Tinnitus Persistence after AcuteAcoustic Trauma. In New Directions for Improving Audio Effectiveness (pp. 4-1 - 4-12). 
9. Campanella L, Bonanni A, Finnoti E, Tomasseti M. Biosensors for determination of total and natural antioxidant capacily of red and white wines. Comparison with other spectrophotometric and fluorimetric methods. Biosens Bioelectron.2004; 19:641.

10. Larry EH, Lois MJ, Jane S. Noise and Noise Induced Hearing Loss in the Military. Dalam Noise and Military Service : Implication for hearing loss and tinnitus. The National Academy Press. http : // www . nap . edu / openbook . php?record_id=11443. 2006. 72-115.

11. Technical Guide (TG) 250, Readiness thru Hearing Conservation, US Army Centre for Health Promotion and Prevention Medicine, MCHB-TS-MHC (Hearing Conservation Program Office) 5158 Blackhawk Road E 1570, 2004.

12. Sataloff TR and Sataloff J. Sensorineural hearing loss. Diagnostic criteria. hearing loss. Second edition. Copyright by Mercel Dekker, Inc. New York. 1993. 253-7.

13. Direktorat Bina Kesehatan Kerja. Pedoman Program Konservasi Pendengaran di Tempat Kerja, Departemen Kesehatan RI. 2006.

14. Tim redaksi Pustaka Yustisia. Undang-Undang Kesehatan dan Rumah Sakit 2009. Yogyakarta: Penerbit Pustaka Yustisia; 2010.

15. Hearing Conservation Program (HCP), US Department of Defence Instruction (DoDI) 6055.12, December 3, 2010.

16. Army Hearing Program, ST 4-02.501, Headquarters Department of the Army, United States Army Medical Department Center and School, Fort Sam Houston, Texas 78234-6100,1 February 2008.

17. Alberti PW. Noise and the ear. Scott Brown's Otolaryngology. Edited by Alan G Kerr. Butterworth-Heinemann. London. 1997;6 (2/11/7-2/11/18).

18. Colleen G, Le Prell, Daisuke Y, Shujiro BM, Tatsuya Y and Josef MM. Mechanism of noise-induced hearing loss indicate methods and prevention. Hear Res.2007 April;226(1-2):22-43.

19. Henderson D, Bielefeld EC, Harris KC, Hu BH. The Role of oxidative stres in noise induced hearing loss. Ear and Hearing : Lippincott Williams \& Wilkins, USA ; 2006.27:1-19.

20. Henderson D, Hu BH, Bielefeld EC. Patterns and Mechanisms of Noise Induced Koklear Pathology. Schact J, Popper AN, Fay R.R Editor. Auditory Trauma, Protection and Repair: Springer Science New York 2008.h.195-217.

21. Kataoka S, Tsuruo T. Physician education: Apoptosis. Oncologist. 1996;1(6):399-401.

22. Ozguner MF, Delibas N, Tahan P, Koyu A, Koylu H. Effects of Industrial noise on the Blood Levels of Superoxide Dismutase. Glutathione Peroxidase and Malondialdehyde. Eastern Journal of Medicine 1999; 4(1): h.13 - 5.

23. Pinar T, Atli A.K, Alacam H, Karabulut I, Soguksulu I, Atas A, Omar M.B, Amin N, Akyol O; Thr Effects of Noise on Oxidative and Antioxidative Balance in Human Erythrocytes;International Journal of Hematology and Oncology;Number I;Vol.21;2011; $10-8$.

24. Finamore A, Devirgiliis C, Panno D, D'Aquino M, Polito A, Venneria E, et al. Immune response in relation to zinc status, sex and antioxidant defence in Italian elderly population: the ZENITH study. European Journal of Clinical Nutrition. 2005;59(2):S68-72.

25. Barry H, John.M.C G, editors. Free Radicals in Biology and Medicine. 2 ed. New York: Oxford University Press; 1989.

26. Kenneth B, Bruce A. The Free Radical Theory of Aging Matures. Physiol Rev. 1998 15 Okt 2009;78:547-81.

27. Scott KP, Malcolm JJ. Exercise-Induced Oxidative Stress: Cellular Mechanisms and Impact on Muscle Force Production. Physiol Rev. 2008;88:1243-76.

28. Wangemann P. Cochlear homeostasis and homeostatic disorders. In: Schacht J, Popper A, editors. Auditory trauma, protection, and repair Springer handBook of auditory research. New York: Springer Science; 2008. p. 49-100. 
29. Donald C, Shan C, Lai-Har C, Samsot J, Donald H. Age-related changes in antioxidant enzymes related to hydrogen peroxide metabolism in rat inner ear. Neuroscience Letters. 2009;464:22-5

30. Lakari E. Expression of oxidant and antioxidant enzyme in human lung and interstitial lung disease. Oulu: Department of Internal Medicine University of Oulu.2005.

31. Hinrich S, Qing-Yin Z, Thomas R-V. Oxidative Stress in Aging in the C57B16/J Mouse Cochlea. Acta Otolaryngol. 2001;121:666-72.

32. Miguel M, Manuel M, Germaine E, Josefa L, Dario A. Melatonin but not vitamins C and E maintains glutathione homeostasis in t-butyl hydroperoxide-induced mitochondrial oxidative stress. FASEB J. 2000.

33. Timothy R. Glutathione Peroxidase Mimics. In: Richard C, Henry R, editors. Critical Reviews of Oxidative Stress and Aging: Advances in Basic Science, Diagnostics and Intervention. Toh Tuck Link, Singapore: World Scientific Publishing Co. Pte. Ltd; 2003. p. 1345.

34. Tong MI, Patricia B, William W. Antioxidant effects of calcium channel blockers against free radical injury in endothelial cells. Correlation of protection with preservation of glutathione levels. Circ Res. 1992;70:1099-103.

35. Mohammed A, El-far-Mohammed A, Bakr-Sami E, Farahat, Elsaid A, Abd E-F. Glutathione peroxidase activity in patients with renal disorders. Clin Exp Nephrol. 2005;9:127-31.

36. Kill J, Pierce C, Tran H, Gu R, Lynch ED. Ebselen treatment reduces noise induced hearing loss via the mimicry and induction of glutathione peroxidase. PubMed. Hear Res. 2007 Apr;226(1-2);44-51. Epub 2006 Oct 6.

37. Lynch ED, Kill J. Development of Ebselen a Glutathione Perixidase Mimic, for the Prevention and Treatment of NoiseInduced Hearing Loss. Thieme Medical Publishers. Semin Hear 2009;30(1):047-055 DOI:10.1055/s-0026-1111106.

38. Darrat I, Ahmad N, Seidman K., Auditory research involving antioxidants. Current Opinion in Otolaryngology A Head and Nack Surgery, Lippincott Williams and Wilkins, 2007, $15: 358-63$

39. Pendyala L. and Creaven PJ.. Pharmacokinetic and Pharmacodynamic Studies of N-asetil sistein, A Potential Chemopreventive Agent during A Phase I Trial. Cancer Epidemiology, Biomarkers and Prevention, Vol. 4, 1995. 245 -51 .

40. Dobie RA. Noise Induce Hearing Loss. Head and Neck SurgeryLaryngology. Second edition. Edited by Byron J Bailey. Lippincott-Raven Publishers. Philadelphia. 1998. Halaman: 2155- 56.

41. Nilland J. Zenz C. Occupational hearing loss, noise, and hearing conservation. Zenz C. (chief ed). Dickerson OB. Horvarth EP. Occupational Medicine. 3rd ed. Mosby. St. Louis: 1994.

42. Regina BF, Leopold F. Is there a role of glutathione peroxidases in signaling and differentiation? BioFactors. 2003;17:93-102.

43. Jochen S. Auditory Pathology: When Hearing Out of Balance. In: Jochen S, Arthur N, Richard R, editors. Auditory Trauma, Protection, and Repair. New York: Springer Science+Business Media; 2008. p. 1-7.

44. Rogerio M, Christophe D, Felipe K, Marcia M. Glutathione peroxidase family - an evolutionary overview. FEBS Journal. 2008;275:3959-70.

45. Tima-Le, Elizabeth K. Effects of antioxidants on the aging inner ear. Hearing Research. 2007;226:194-202.

46. Marc.AF, Norbert W, Stanley H, Andre C, Elizabeth.SK, Charlene B, et al. Cellular glutathione peroxidase deficiency and endothelial dysfunction. Am J Physiol Heart Circ Physiol. 2002;282:1255-61.

47. Stephane H, Patricia R-D, Joel R. Seleno-independent glutathione peroxidases, More than simple antioxidant scavengers. FEBS Journal 274. 2007:2163-80.

48. Oxford Biomedical Research. Colorimetric assay for cellular glutathione peroxidase. USA:2005. 
49. Shay J, Wright W. Senescence and immortalization: role of telomeres and telomerase. Carcinogenesis. 2005;26(5):86774.

50. Diamond G. Aging and Apoptosis [diunduh 19 Juni 2010]: Available from: http://www.ehow.com/about_5593346_aging-apoptosis.html.

51. Van-Eyken E, Van-Camp G, Van-Laer L. The Complexity of Age-Related Hearing Impairment: Contributing Environmental and Genetic Factors. Audiol Neurotol. 2007;12:345-58.

52. George A, Thomas S. Hear ye? Hear ye! Successful auditory aging. . West J Med. 1997;167(247-52).

53. Poirrier A.L, Pincemail J., Van Den Ackerveken P., Lefebvre1 P.P. and Malgrange B., Oxidative Stress in the Cochlea. (C) 2010 Bentham Science Publishers Ltd. Update Current Medicinal Chemistry, 2010 Vol. 17, No. 31(1-15).

54. Kil J, Lynch ED, Ashley J, Kawasaki JH, Noise and drug - induced hair cell injury and death. http : // www. soundpharmaceuticals. Co / tehnology. html. 2010.

55. Lin CY, Wu J-L, Shih T-S, Tsai P-J, Sun Y-M, Mag M-C, Guo YL, N-asetil sistein against noise-induced temporary threshold shift in male workers. Hearing Research 269. 2010. 42-7.

56. Best B. N-asetil sistein (NAC). http : // www. benbest. Com / nutrceut / NAC / html. 2010 (1-4).

57. Braga PC. Oxidative stres respiratory diseases and tiol compound. Pacini Editore Spa:Pisa, Italy;2006.

58. Campbell KCM. Otoacoustic emission. Departmeny of surgery. Division of otolaryngology, Southern Ilionis University of medicine, 2006. Availableat : http // www.emedicine.com /ent/topic372.htm.

59. Dhar S \& Hall JW III. (2010). Otoacoustic Emissions: Principles, Procedures, and Protocols. National Library of Medicine website (www.nlm.nih.gov, Health Care Professionals). San Diego: Plural Publishing

60. Granot E, Kohen R. Oxidative stres in abetalipoproteinemia patients receiving long-term vitamin E and vitamin A supplementation. Am J Clin. Nurt, $2004 ; 79: 226-30$.

61. Cayman Chemical Company. Ebselen. Item number 70530(CAS 60940-34-3). https : // www. caymanchem. Com / template / product. Vm / catalog /7. copyright 2011.

62. Liu A. Glutathion Peroxidase mimics : Ebselen. For 77:222, Spring 2005., 24,February 2005 pp. 1-12.

63. Fijisawa S, Kadoma T. Kinetic Studies of the Radical-scavenging Activity of Ebselen, a Seleno-organic Compound. Anticancer Research 25; 3989-3994. 2005.

64. Schewe.T Molecular actions of Ebselen-an anti-inflammatory antioxidant. General Pharmacology:The Vascular System Volume 26. Issue 6,October 1995. 1153-69.

65. Bashiruddin J, Program Konservasi Pendengaran pada Pekerja yang Terpajan Bising Industri, Majalah Kedokteran Indononesia, Volum: 59, Nomor: 1, Januari 2009

66. Husein A, WT K, Dahlan A-M, Aswitha B, Ismet N. Desain Penelitian. In: Sudigdo S, Sofyan I, editors. Dasar-dasar Metodologi Penelitian Klinis. 3 ed. Jakarta: CV Sagung Seto; 2010. p. 92-111.

67. Eko B. Metodologi Penelitian Kedokteran: sebuah pengantar. Jakarta: Penerbit Buku Kedokteran EGC; 2004.

68. Joko S, editor. Memahami Penelitian Kedokteran: Pedoman seorang praktisi. 1 ed. Jakarta: Penerbit Hipokrates; 2002.

69. Madiyono B, Moeslichan S, Sastroasmoro S, Budiman I, Purwanto S. Perkiraan besar sampel. In: Sastroasmoro S, Ismael S, editors. Dasar-dasar metodologi penelitian klinis. 3 ed. Jakarta: CV Sagung Seto; 2008. p. 302-31.

70. Bhisma M. Desain dan Ukuran Sampel untuk Penelitian Kuantitatif dan Kualitatif di Bidang Kesehatan. 1 ed. Yogyakarta: Gadjah Mada University Press; 2006. 
71. Woolson RF.. Sample size considerations. Dalam : Statistical methods for the analysis of biomedical data. Wiley series in probability and mathematical statistics. 1987. $352-56$.

72. Jacobson GA, Yee KC, Ng CH. Elevated plasma glutathione peroxidase concentration in acute severe asthma: Comparison with plasma glutathione peroxidase activity, selenium and malondialdehyde. Scand J Clin Lab Invest. 2007;67:423-30.

73. Campanella L, Bonanni A, Finnoti E, Tomasseti M. Biosensors for determination of total and natural antioxidant capacily of red and white wines. Comparison with other spectrophotometric and fluorimetric methods. Biosens Bioelectron.2004; 19:641. 